Mr Zoran Ristic, pukovnik, dipl. inž.

Sc Milisav Jakovljević, potpukovnik, dipl. inž.

\section{ANALIZA RADA LANSIRNOG ARTILJERIJSKOG SISTEMA}

\section{Uvod}

Elastična veza između trzajuće mase i nepokretnog dela artiljerijskog oruđa omogućuje da se u toku procesa opaljenja kratkotrajni impuls ogromne sile pritiska barutnih gasova $\mathbf{P}_{\mathbf{z}}$ transformiše $u$ dugotrajni impuls znatno manje sile otpora trzanju R. Na taj način se smanjuje opterećenje lafeta, što omogućava smanjenje njegovih dimenzija i mase.

Smanjenje sile otpora trzanju $\mathrm{R}$ ograničeno je ukupnom dužinom trzanja. U težnji da se dejstvo sile pritiska barutnih gasova $P_{z}$ na lafet oruđa još više smanji, došlo se na ideju da se pre izvršenja opaljenja, cevi artiljerijskog sistema »saopšti« izvesna brzina kretanja u smeru kretanja projektila, tj. suprotno smeru trzanja. $\mathrm{Na}$ taj način bi u procesu opaljenja došlo do preraspodele ukupnog impulsa sile barutnih gasova, pri čemu bi se jedan deo trošio na zaustavljanje trzajuće mase, a drugi, smanjeni deo, na samo trzanje cevi. Pri tome se smanjuje i ukupna energija koju artiljerijski sistem treba da apsorbuje na pripadajućoj ili raspoloživoj dužini trzanja. Time se stvara mogućnost da se smanje krutost sistema, dimenzije i masa nepokretnih delova pa, prema tome, i ukupna masa oruđa.

Artiljerijski sistem koji radi na ovom principu predstavlja »lansirni artiljerijski sistem« (LAS).
Pokušaji primene ovakvih sistema vršeni su u nekim zapadnim zemljama, ali kao takav još uvek nije doživeo afirmaciju u savremenim artiljerijskim konstrukcijama. Bez obzira na to, ne$\mathrm{ka}$ istraživanja $\mathrm{i}$ objavljeni radovi $\mathrm{u}$ svetu upućuju na ideju da su teorijska razmatranja ove problematike svakako aktuelna, s obzirom na mogućnost kompromisa u zahtevima za moćnim artiljerijskim sistemima i njihovom pokretljivošću.

Teorijske osnove principa rada LAS, kao i važnije preporuke za određivanje elemenata lansiranja i trzanja cevi objašnjene su u literaturi [1]. Polazeći od toga, $u$ ovom radu je bez većih objašnjenja, osim gde je neophodno, dat matematički model LAS-a $\mathrm{u}$ obliku koji omogućuje primenu numeričkih metoda. Matematički model, formalizovan preko diferencijalnih jednačina kretanja cevi u fazi lansiranja i trzanja, rađen je za uslove koje LAS mora obezbediti primenom na postojećim konstrukcijama artiljerijskih oruđa. Pri tome su definisane neophodne minimalne konstruktivne izmene klasičnog artiljerijskog sistema, uz definisanje trenutka opaljenja i obezbeđenje stabilnosti LAS.

$\mathrm{Za}$ razmatrani model LAS razrađen je algoritam za programsko rešenje modela i određivanje svih relevantnih veličina i parametara. Simulacijom prikazanog modela, za definisane 
polazne podatke izvedenog lafetnog oruđa, dobijeni su rezultati koji su potpuno saglasni sa podacima $u$ široj literaturi.

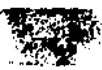

\section{Princip rada LAS}

Lansiranjem trzajuće mase $u$ smeru kretanja projektila vrši se raspodela impulsa pritiska barutnih gasova $u$ cevi na dva dela (sl. 1):

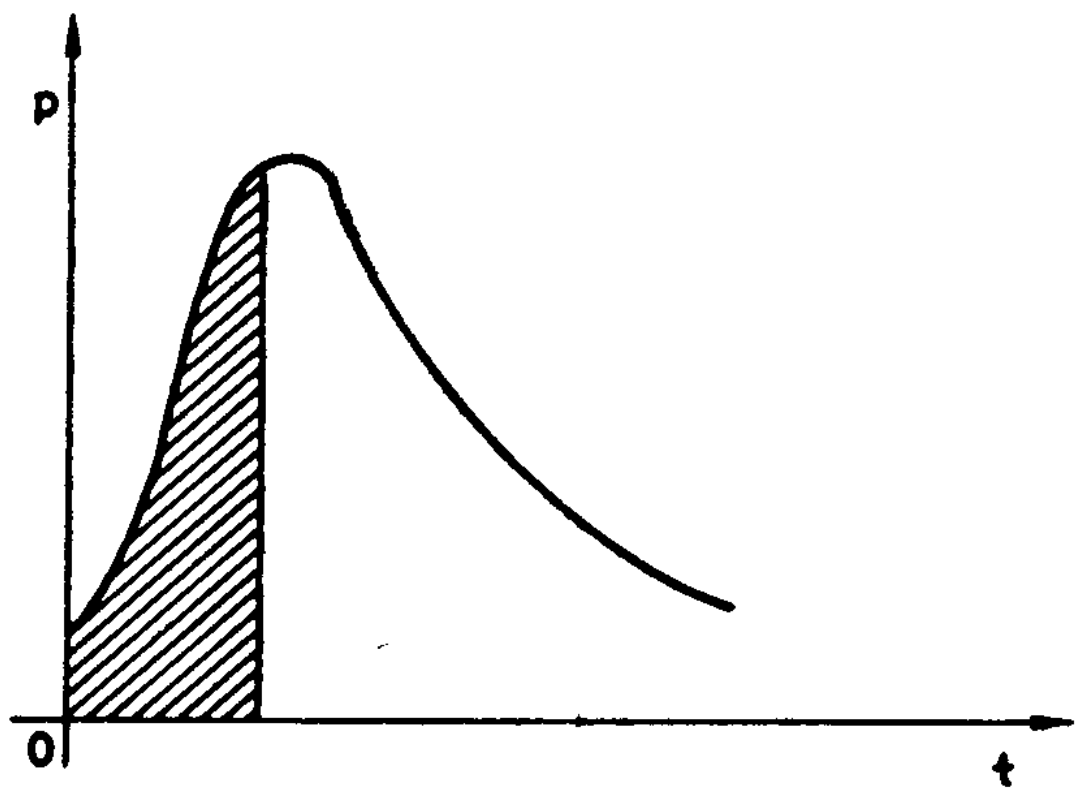

Sl. 1 - Sema raspodele impulsa pritiska barutnih gasova

- manji deo koji zaustavlja kretanje trzajuće mase (šrafirano područje),

- veći deo koji ubrzava trzajuću masu u smeru trzanja.

Da bi se to ostvarilo, potrebno je da cev, pre opaljenja metka, bude u zadnjem položaju, tj. da bude "zapeta«. U taj položaj cev se može dovesti neposredno pre gađanja ili da to bude stalni položaj cevi (čak i pri transportu).

Energija potrebna za pokretanje - lansiranje cevi, može da bude akumulirana u povratniku koji je sastavni deo klasičnog protivtrzajućeg uređaja (PTU) oruđa. U željenom trenut$\mathrm{ku}$, cev se otpušta i, posle izvesnog pređenog puta, kada se dostigne određena brzina kretanja unapred (lansiranje), izvrši se opaljenje. Dejstvom sile pritiska barutnih gasova na dno cevi prvo se vrši zaustavljanje lansirane trzajuće mase, a zatim nastupa njeno pokretanje u smeru trzanja, tj. nastupa period klasičnog trzanja.

Karakter promene brzine lansiranja prikazan je šematski na slici 2.

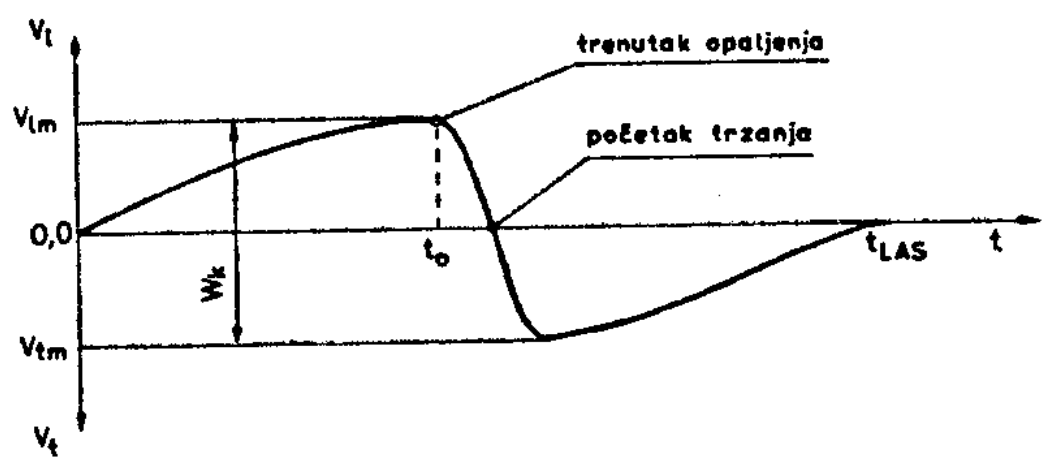

Sl. 2 - Promena brzine lansiranja

gde je:

$\mathrm{V}_{\mathrm{Im}}$ - brzina lansiranja $\mathrm{u}$ trenutku opaljenja (maksimalna brzina lansiranja),

$\mathrm{V}_{\mathrm{tm}}$ - maksimalna brzina trzanja,

$$
\left|\mathbf{W}_{\mathrm{k}}\right|=\left|\mathrm{V}_{\mathrm{lm}}\right|+\left|\mathrm{V}_{\mathrm{tm}}\right|
$$

$\mathrm{W}_{\mathrm{k}}$ - brzina slobodnog kretanja cevi na kraju perioda isticanja barutnih gasova.

U slučaju kada nema lansiranja, za dato barutno punjenje, maksimalna brzina trzanja bila bi jednaka brzini slobodnog trzanja $\left|W_{k}\right|$, ali, s obzirom na proces lansiranja (energije potrebne za lansiranje i druge otpore, smanjena je na $\left|V_{\mathrm{tm}}\right|$. Naravno, to vredi ukoliko LAS ima istu konstruktivnu šemu kočnice lansiranja, odnosno trzanja, kao i pripadajući klasičan artiljerijski sistem.

Iz teorije klasičnih lafeta poznato je da ukupna masa oruđa zavisi od energije trzajućih delova [3]. Pošto se procesom lansiranja brzina kretanja trzajuće mase praktično smanjuje, realizacijom principa LAS može se očekivati znatno smanjenje energije trzanja.

Energija trzanja se, inače, smanjuje principijelno na dva načina: pove- 
ćanjem mase trzajućih delova i ugradnjom gasne kočnice na cev oruđa. Praksa je pokazala da je najpogodniji odnos mase trzajućih delova prema masi oruđa [3]:

$\chi=0,4$ do 0,5 za vučna oruđa sa dvokrakim lafetom.

Za razmatranja koja slede mnogo značajniji je »koeficijent iskorišćenja mase lafeta«, koji je jednak odnosu kinetičke energije trzanja prema ukupnoj masi lafeta:

$$
\eta_{l}=\frac{E_{t}}{M}=\frac{0,5 \cdot M \cdot V_{t m}^{2}}{M}
$$

Uspešnost konstrukcije ogleda se upravo $u$ tome da koeficijent $\eta_{1}$ bude što je moguće veći, uz obezbeđenje potrebne stabilnosti oruđa.

$\mathrm{Za}$ jedan idealni LAS, kod koga nema gubitaka usled trenja i koji nema kočnicu lansiranja $i$ trzanja, tj. postoji samo delovanje barutnih gasova na trzajuću masu i dejstvo sile povratnika na celom putu lansiranja i trzanja, može se uspostaviti "ravnoteža", odnosno jednakost dužine lansiranja prema dužini trzanja. U tom slučaju može se pretpostaviti da je:

$$
\mathrm{V}_{\mathrm{lm}}=\mathrm{V}_{\mathrm{tm}}=\frac{\mathrm{W}_{\mathrm{k}}}{2}
$$

Znači da se idealni LAS može praktično rešiti tako da proces lansiranja i proces trzanja budu potpuno inverzni. U tom slučaju odnos između energija trzanja LAS i klasičnog artiljerijskog sistema bio bi:

$$
\eta_{\mathrm{E}}=\frac{\mathrm{E}_{\mathrm{t}}}{\mathrm{E}_{\mathrm{k}}}=\frac{\mathrm{M} \cdot\left(0,5 \cdot \mathrm{W}_{\mathrm{k}}\right)^{2}}{M \cdot \mathrm{W}_{\mathrm{k}}^{2}}=0,25
$$

To znači da je kod LAS energija trzanja svedena na $25 \%$ energije trzanja klasičnog sistema, tj. teorijski smanjena za $75 \%$.

$\mathrm{U}$ realnim uslovima kada postoji sila trenja na klizačima kolevke koja se ne može zanemariti i kada se kori- sti dvodelni metak sa različitim punjenjima (različite početne brzine projektila), gde je potrebna kočnica lansiranja, smanjenje energije trzanja $u$ odnosu na klasični artiljerijski sistem će biti manje od $75 \%$. S druge strane, rad LAS-a kod kojeg je $V_{\mathrm{lm}}>\frac{\mathrm{V}_{\mathbf{k}}}{2}$ bio bi nestalan, i zahtevao bi znatno komplikovanije rešenje elemenata PTU. Pri proračunu LAS treba težiti idealnoj granici (od 75\%), uz obezbeđenje stabilnosti sistema. U tom smislu prihvatljivo rešenje su hidraulične kočnice sa konstantnim protočnim otvorima.

Prema tome, projektovanjem LAS omogućeno je smanjenje nepokretnih delova oruđa uz istu čvrstoću i krutost sistema, pojednostavljenje PTU, izbegavanje upotrebe gasne kočnice, i sl.

\section{Zahtevi za izradu LAS}

LAS mora da zadovolji nekoliko zahteva, kako bi njegova upotreba bila moguća i opravdana a to su:

\section{a) stabilnost $i$ nepomičnost}

Uslov stabilnosti LAS, odnosno odsustvo pomeranja oruđa $u$ vertikalnoj ravni, biće ispunjen ako pri lansiranju i trzanju uvek postoji kontakt prednjeg oslonca oruđa (točkova ili podloge za gađanje) i tla. Uslov nepomičnosti odnosno odsustvo pomeranja oruđa u horizontalnoj ravni, biće ispunjen ako je reakcija tla na lafet (sila trenja) veća od horizontalne komponente sile otpora pri lansiranju, odnosno trzanju;

\section{b) "ravnoteža" lansiranje - trzanje}

Odnosi se na zahtev jednakosti pređenih puteva pri lansiranju i trzanju. Ukoliko bi dužina lansiranja bila veća od dužine trzanja, trzajuća masa ne bi mogla da dođe do položaja za zapinjanje, dok bi u suprotnom slu- 
čaju trzajuća masa imala veću kinetičku energiju, što znači da bi režim rada bio nestalan.

Ovaj uslov može se ispuniti ugradnjom hidraulične kočnice lansiranja $\left(\mathrm{HK}_{\mathrm{l}}\right)$ i hidraulične kočnice trzanja $\left(\mathrm{HK}_{\mathrm{t}}\right)$ koje će obezbediti da dužina lansiranja i dužina trzanja budu u $\varepsilon_{o}$ okolini zahtevane dužine za konkretni LAS. Pri tome je važno da brzina lansiranja u trenutku opaljenja mora biti:

$$
\mathrm{V}_{\mathrm{lm}} \leqslant \frac{\mathrm{W}_{\mathrm{k}}}{2}
$$

Za uslov ravnoteže neophodan je proračun odgovarajućih površina otpora $\mathrm{HK}_{\mathbf{l}}$ i $\mathrm{HK}_{\mathrm{t}}$.

Izbor trenutka opaljenja na određenoj dužini lansiranja od izuzetne je važnosti za pravilnu funkciju LAS, a ujedno i veoma delikatna operacija, s obzirom na postojanje slobodnih hodova u mehanizmima za okidanje, inertnost procesa pripaljivanja osnovnog punjenja, itd. Navedena razmatranja ravnopravno se odnose za slučajeve oruđa sa i bez gasne kočnice, s tim što je učinak delovanja gasne kočnice na proces trzanja poznat. Međutim, gasnu kočnicu treba izbeći svuda gde je efekat lansiranja sasvim dovoljan;

\section{c) minimalne konstruktivne izmene klasičnog artiljerijskog sistema}

S obzirom na to da se LAS projektuje na osnovu izvedenog klasičnog artiljerijskog sistema, a imajući $u$ vidu minimalne i ekonomski opravdane zahteve, daju se sledeće preporuke [1]:

- koristiti povratnik istog tipa kao kod klasičnog artiljerijskog sistema, uz mogućnost povećanja početne sile (promenu početne sile),

- za kočnicu lansiranja i trzanja koristiti kočnicu trzanja i vraćanja klasičnog artiljerijskog sistema sa konstantnim protočnim otvorima, čija je veličina utvrđena proračunom LAS,
- ako postoji, gasna kočnica se koristi bez izmene na LAS,

- masa trzajućih delova je ista kao kod klasičnog artiljerijskog sistema ili sa što manjim izmenama,

- ugraditi uređaj za "zapinjanje» trzajuće mase u početnom - zadnjem položaju,

- konstruktivnim izmenama obezbediti automatsko okidanje na određenoj (proračunatoj) dužini lansiranja,

- smanjiti masu lafeta, uz obezbeđenje potrebne čvrstoće i krutosti njegovih elemenata $\mathrm{i}$ uslova stabilnosti i nepomičnosti.

\section{Opis matematičkog modela LAS}

Matematičkim modelom opisano je dinamičko ponašanje LAS u procesu lansiranja i trzanja, kao i uslovi stabilnosti i nepomičnosti LAS-a za vreme opaljenja. U slučaju neizvršenja opaljenja, razmotren je uticaj dejstva sile amortizera na stabilnost LAS za vreme lansiranja trzajuće mase (lansiranje cevi).

Zbog obimnosti izvođenja izostavljen je detaljan opis modela, a radi lakšeg razumevanja prikazan je sistem diferencijalnih $i$ algebarskih jednačina u konačnom obliku sa neophodnim objašnjenjima za numeričko rešavanje.

\section{Proces lansiranja cevi}

Lansiranje cevi vrši se iz zapetog položaja preko akumulirane energije hidropneumatskog povratnika. Za promenu sile povratnika važe isti zakoni kao i kod klasičnog povratnika oruđa [4]. Proces lansiranja obuhvata dva perioda (sl. 3):

- prvi period od početka lansiranja do trenutka opaljenja,

- drugi period od trenutka opaljenja do zaustavljanja cevi.

$\mathrm{Na}$ osnovu analize sila za LAS sa hidropneumatskim povratnikom $i$ hi- 


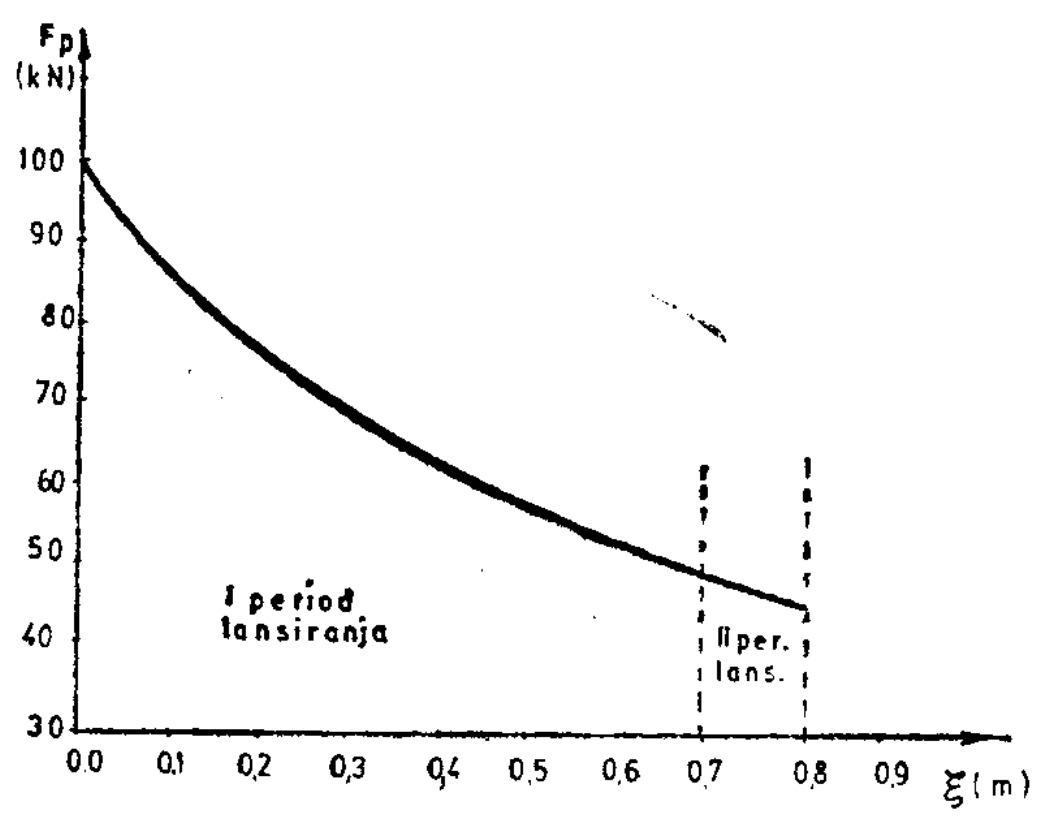

Sl. 3 - Promena sile povratnika u procesu lansiranja

drauličnom kočnicom lansiranja, diferencijalna jednačina kretanja trzajuće mase $u$ procesu lansiranja glasi:

$M \frac{d^{2} \zeta}{{d t^{2}}^{2}}=F_{p}-F_{t r}-Q_{o} \sin \varphi-F_{k l}-C_{1} \cdot F_{b}$

gde je:

M - masa trzajućih delova,

$\zeta$ - put lansiranja,

$F_{p}=F_{p o} \cdot\left(\frac{S_{o}}{S_{o}-X}\right)^{n}-$ sila povratnika

(ubrzava trzajuću masu),

$F_{t r}=Q_{0} \cdot(f \cdot \cos \varphi+\nu)$ - sila trenja (usporava trzajuću masu),

$\mathrm{Q}_{0} \cdot \sin \varphi$ - komponenta sile težine trzajuće mase,

$\mathrm{F}_{\mathrm{kl}}=\frac{\mathrm{V}^{2}}{\mathrm{~A}_{1}}-$ sila kočnice lansiranja,

$F_{b}=S \cdot b_{1} \cdot p(t)-$ sila pritiska barutnih gasova na trzajuću masu u drugom periodu lansiranja,

$\mathrm{C}_{1}$ - koeficijent uključenja (isključenja) delovanja sile $F_{b}\left(C_{1}=0\right.$ za pr- vi period i $C_{1}=1$ za drugi period lansiranja).

Oznake navedenih veličina su:

$F_{p o}=Q_{o} \cdot\left(f \cdot \cos \varphi_{m}+\nu+\sin \varphi_{m}\right)+\frac{V_{l m}^{2}}{A_{l}}-$

- početna sila povratnika,

$\mathrm{S}_{\mathrm{o}}=\mathrm{L} \cdot \mathrm{m} / \mathrm{m}^{\frac{1}{\mathrm{n}}}-1-$ početna visina gasnog stuba povratnika,

L - ukupni put lansiranja,

$\mathrm{X}$ - trenutna udaljenost trzajuće mase od prednjeg (zapetog) položaja (za lansiranje $\mathrm{X}=\mathrm{L}-\zeta$, za trzanje $X=\lambda$ ),

$\mathrm{m}, \mathrm{n}$ - stepen kompresije i koeficijent politrope za povratnik,

f, $\nu$ - koeficijenti mehaničkog i hidrauličnog trenja PTU,

$\varphi$ - ugao elevacije cevi $\left(\varphi_{\mathfrak{m}}-\max\right.$. ugao),

$\mathrm{V}_{1}$ - brzina lansiranja,

$A_{l}$ - karakteristika kočnice lansiranja,

S - površina poprečnog preseka kanala cevi,

$\mathrm{p}(\mathrm{t})$ - srednji pritisak barutnih gasova u cevi,

$\mathrm{b}_{1}$ - konstanta, zavisi od izraza za pritisak na dno cevi [4].

\section{Proces traanja cevi}

Proces trzanja cevi počinje $u$ trenutku zaustavljanja lansirane mase i obuhvata tri perioda, analogno šemi usvojenoj u teoriji lafeta [3]. Prvi period trzanja traje od trenutka zaustavljanja cevi pri lansiranju do trenutka kada projektil napusti cev, drugi period traje za vreme isticanja barutnih gasova iz cevi i treći je period trzanja koji obuhvata kretanje po inerciji do zaustavljanja cevi. 
Uzimajući u obzir karakteristike promene pritiska barutnih gasova $u$ cevi $p(t)$ za vreme trzanja, kao i sve relevantne sile, diferencijalna jednačina kretanja za celi proces trzanja može se napisati u obliku:

$$
\begin{aligned}
& M \frac{d^{2} \lambda}{d^{2}}=C_{2} \cdot F_{b}+Q_{0} \cdot \sin \varphi-F_{p}-F_{t r}- \\
& -F_{k t}-C_{3} \cdot F_{g k}
\end{aligned}
$$

gde je:

$\lambda$ - put trzanja,

$F_{g k}=\frac{(1-\alpha) \cdot \beta}{\beta-0,5} F_{b}(\tau)-$ sila gasne kočnice [2],

$\alpha$ - konstruktivna karakteristika gasne kočnice,

$\beta-$ koeficijent naknadnog dejstva barutnih gasova,

$F_{b}(\tau)=S \cdot b_{1} \cdot p(t)$ - sila pritiska barutnih gasova na cev $\mathrm{u}$ periodu isticanja.

Za zakon promene pritiska gasova $p(t) u$ toku isticanja iz cevi usvojen je eksponencijalni oblik Bravina [2]:

$$
p(t)=p_{u} \cdot e^{-t / b}
$$

gde je:

$\mathrm{p}_{\mathrm{u}}$ - pritisak barutnih gasova na ustima cevi,

b - parametar isticanja,

$t$ - vreme isticanja barutnih gasova.

Ugradnja hidraulične kočnice trzanja u sklopu LAS, s obzirom na obezbeđenje uslova "ravnoteže "lansiranje - trzanje, predstavlja jedno od mogućih rešenja. $U$ tom smislu, ovakva kočnica treba da bude projektovana tako da zadovolji sledeće zahteve: stvuje,

- da u periodu lansiranja ne dej-

- da u prvom i drugom periodu trzanja protočni otvori budu toliko veliki da je sila kočenja $F_{\mathrm{kt}}$ zanemarljiva,
- da na putu kočenja, u trećem periodu, protočni otvori budu konstantni.

Sa ovakvim otvorima zakon promene sile hidraulične kočnice trzanja, slično kočnici lansiranja, dat je izrazom [4]:

$$
F_{k t}=\frac{k \rho}{2} \cdot \frac{A^{3}{ }_{k}}{a^{2} \lambda} V_{t}^{2}=V_{t}^{2} / A_{t}
$$

gde je:

k - koeficijent otpora proticanja,

$\rho$ - gustina hidraulične tečnosti,

$A_{k}$ - efektivna površina klipa kočnice,

$a_{\lambda}$ - promenljiva protočna površina,

$\mathrm{V}_{\mathrm{t}}$ - brzina trzanja,

$A_{t}$ - karakteristika kočnice trzanja.

Oznake ostalih veličina prema (2) iste su kao i u relaciji (1) sa datim objašnjenjima. Važno je napomenuti da su koeficijenti delovanja sila $u$ procesu trzanja $C_{2}$ i $C_{3}$ definisani na sledeći način:

$\mathrm{C}_{2}=0$ za treći period trzanja i $\mathrm{C}_{2}=1$ za prvi i drugi period trzanja, $\mathrm{C}_{3}=0$ za prvi i treći period trzanja i $\mathrm{C}_{3}=1$ za drugi period trzanja.

Jednačine kretanja (1) i (2) za proces lansiranja i trzanja date su u generalizovanom obliku. Njihovo transformisanje $u$ oblik pogodan za numeričko rešavanje, vodeći računa o periodima za oba procesa, podrazumeva definisanje potrebnih vrẹmena $u$ kojima se celi proces realno odvija.

Ako se pretpostavi delovanje pritiska barutnih gasova $p(t) u$ celom ciklusu rada LAS (proces lansiranja i trzanja), njegova se promena može definisati u sledećem obliku:

$p(t)=\left\{\begin{array}{ll}0 \text { za } & t<t_{o} \\ p(t) z a & t_{o} \leqslant t<t_{u}+t_{o}+\tau \\ 0 \text { za } & t \geqslant t_{o}+t_{u}+\tau\end{array}\right\}$ 
gde je:

$t$ - trenutno vreme od početka lansiranja (tekuće vreme),

$t_{0}$ - vreme trenutka opaljenja,

$t_{1}$ - vreme od trenutka opaljenja do zaustavljanja lansirane cevi (trzajuće mase),

$\tau$ - vreme naknadnog dejstva barutnih gasova,

$t_{u}=t_{1}+t_{2}-$ ukupno vreme kretanja projektila u cevi,

$t_{2}$ - vreme od trenutka zaustavljanja lansirane cevi do trenutka kad projektil izađe iz cevi,

$t_{t}=t_{2}+\tau+t_{3}-$ ukupno vreme trzanja,

$t_{3}$ - vreme od kraja dejstva barutnih gasova do zaustavljanja trzajuće mase,

$t_{1}=t_{0}+t_{1}-$ ukupno vreme lansiranja cevi,

$t_{L A S}=t_{1}+t_{t}$ - vreme trajanja ciklusa rada LAS.

$\mathrm{Na}$ osnovu toga, vrednosti koeficijenata delovanja sila su:

$$
\begin{aligned}
& \mathrm{C}_{1}=\left[\begin{array}{lll}
0 & \text { za } & \mathrm{t}<\mathrm{t}_{\mathrm{o}} \\
1 & \text { za } & \mathrm{t}_{\mathrm{o}} \leqslant \mathrm{t} \leqslant \mathrm{t}_{1}
\end{array}\right] \\
& \mathrm{C}_{2}=\left[\begin{array}{lll}
0 & \mathrm{za} & \mathrm{t}_{\mathrm{o}}+\mathrm{t}_{\mathrm{u}}+\tau<\mathrm{t} \leqslant \mathrm{t}_{\text {LAS }} \\
1 & \text { za } & \mathrm{t}_{1}<\mathrm{t} \leqslant \mathrm{t}_{\mathrm{o}}+\mathrm{t}_{\mathrm{u}}+\tau
\end{array}\right] \\
& C_{3}=\left[\begin{array}{lll}
0 & \text { za } & t<t_{o}+t_{u} \\
1 & \text { za } & t_{o}+t_{u} \leqslant t \leqslant t_{o}+t_{u}+\tau \\
0 & \text { za } & t_{o}+t_{u}+\tau<t \leqslant t_{L A S}
\end{array}\right]
\end{aligned}
$$

Ako se $u$ jednačinama (1) i (2) uvedu izrazi za sile i ostale navedene veličine, a brzina lansiranja i trzanja izrazi preko odgovarajućih puteva, onda se konačni sistem diferencijalnih jednačina kretanja za proces lansiranja dobija u sledećem obliku:

$\mathrm{M} \cdot \frac{\mathrm{dV}}{\mathrm{dt}}=\mathrm{F}_{\mathrm{po}} \cdot\left[\mathrm{S}_{\mathrm{o}} /\left(\mathrm{S}_{\mathrm{o}}-\mathrm{L}+\zeta\right)\right]^{\mathrm{n}}-\mathrm{Q}_{\mathrm{o}}$ $\cdot(f \cdot \cos \varphi+\nu+\sin \varphi)-V^{2} / A_{1}-C_{1} \cdot S \cdot$

$b_{1} \cdot p(t)$

$\mathrm{V}_{\mathrm{l}}=\mathrm{d} \zeta / \mathrm{dt}$

a za proces trzanja:

$M \cdot \frac{d V_{t}}{d t}=C_{2} \cdot S \cdot b_{1} \cdot p(t)\left[1-C_{3} \cdot(1-\alpha) \cdot\right.$

$\cdot \beta /(\beta-0,5)]-F_{p o} \cdot\left(S_{o} /\left(S_{o}-\lambda\right)\right)^{n}-Q_{o} \cdot$

$\cdot(f \cdot \cos \varphi+\nu-\sin \varphi)-\frac{V_{t}^{2}}{A_{t}}$

$\mathrm{V}_{\mathrm{t}}=\frac{\mathrm{d} \lambda}{\mathrm{dt}}$

Sistem jednačina (3) do (6) podesan je za rešavanje numeričkom integracijom pomoću metode Runge-Kutta sa promenljivim koeficijentima. Kao rešenje dobijaju se parametri kretanja trzajuće mase: $V_{1}(t), \zeta(t), V_{t}(t), \lambda(t), u z$ uslov jednakosti dužine lansiranja $i$ dužine trzanja, kao i potrebne stabilnosti LAS.

Vremena za određivanje koeficijenata delovanja sila $\left(C_{1}\right.$ do $\left.C_{3}\right)$ dobijaju se UB proračunom, osim vremena trenutka opaljenja $t_{0}$. Trenutak opaljenja može se rešiti iz uslova maksimalnog smanjenja energije trzanja i pretpostavku da je otpor kočnice pri lansiranju i trzanju jednak. Analizom odnosa impulsa trzajuće mase za proces trzanja i lansiranja, približno vreme opaljenja određuje se relacijom: $t_{0}=t_{1}-t_{1}$.

Važno pitanje $u$ analizi rada LAS jeste problem uslova stabilnosti LAS za vreme lansiranja i trzanja. Treba napomenuti da se stabilnost LAS određuje istom metodologijom kao u slučaju klasičnog artiljerijskog oruđa [3].

Sa stanovišta stabilnosti, bitne su sledeće karakteristike veličine lafeta i sile na lafet oruđa (sl. 4):

$D_{0}$ - rastojanje težišta oruđa od oslonca ašova pre opaljenja, 
$D_{\mathbf{k}}$ - rastojanje tačke oslonca točkova do oslonca ašova,

$\mathrm{h}_{\mathrm{a}}=\mathrm{H}_{\mathrm{o}} \cdot \cos \varphi-\mathrm{L}_{\mathrm{c}} \cdot \sin \varphi-\mathrm{krak}$ inercijalne sile trzajuće mase,

$\mathrm{H}_{\mathrm{o}}=\mathrm{H}+\Delta \mathrm{H}-$ krak sile ukupnog otpora trzanju pri uglu elevacije $\varphi=0 \mathrm{rad}$,

$\mathrm{L}_{c}$ - horizontalno rastojanje ose ramena kolevke do oslonca ašova,
Stabilnost $i$ nepomičnost lafeta u procesu lansiranja

Ako se sila ukupnog otpora $\mathrm{R}$ za proces lansiranja definiše u obliku:

$R=F_{p}-Q_{0} \cdot(f \cdot \cos \varphi+v)-V_{1}^{2} / A_{1}$

onda se moment stabilnosti oruđa oko ašova određuje izrazom:

$\mathrm{M}_{\mathrm{sta}}=\mathrm{Q}_{\mathrm{b}} \cdot \mathrm{D}_{\mathrm{o}}-\mathrm{Q}_{\mathrm{o}} \cdot \mathrm{X} \cdot \cos \varphi-\mathrm{C}_{1} \cdot \mathrm{F}_{\mathrm{kn}} \cdot$

$\cdot \mathrm{e}-\left(\mathrm{R}-\mathrm{Q}_{0} \cdot \sin \varphi\right) \cdot \mathrm{h}_{\mathrm{a}}$

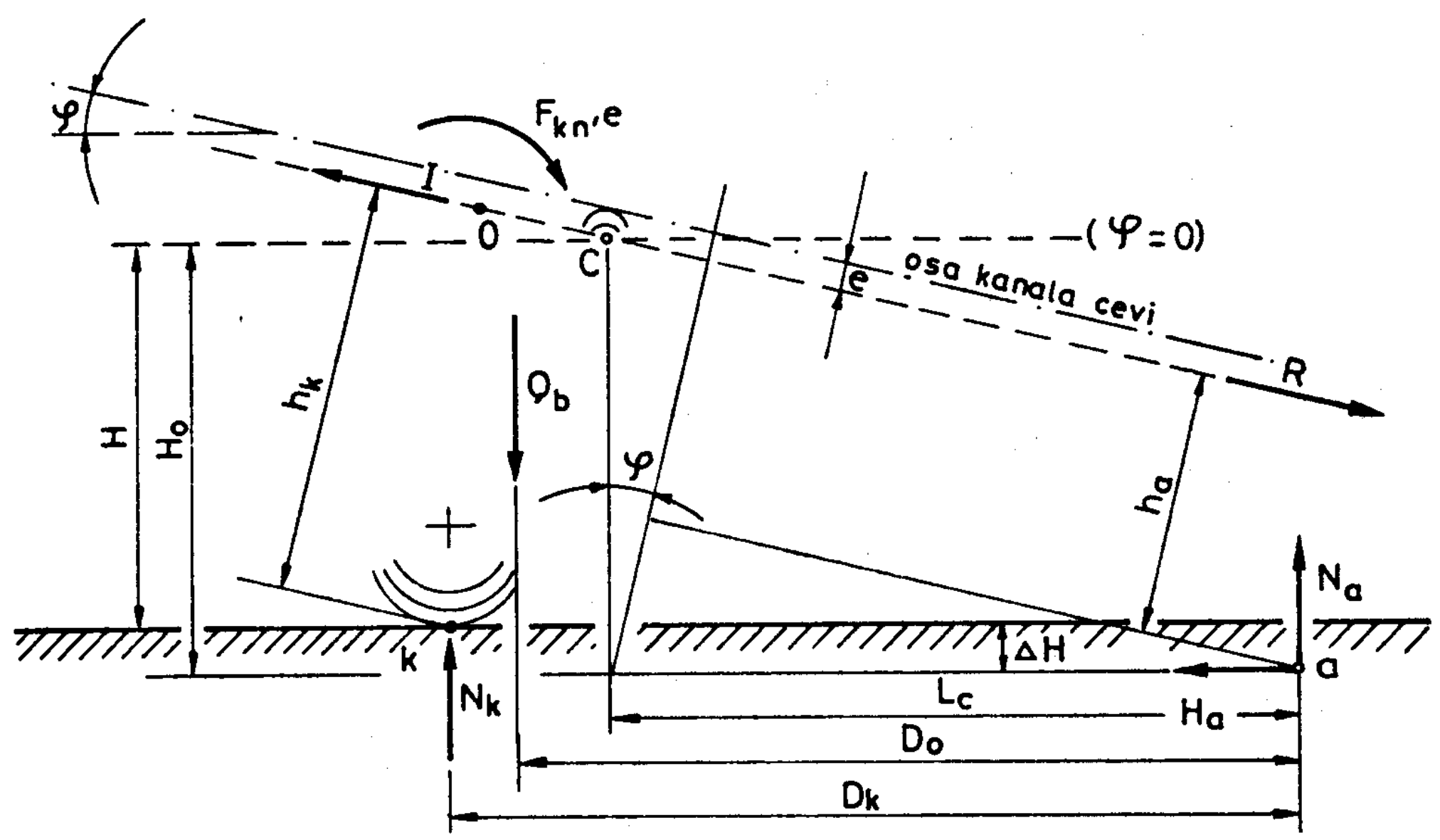

Sl. 4-Dejstvo sila na lafet pri lansiranju - trzanju

$F_{k n}$ - rezultantna sila $u$ kanalu cevi za vreme dejstva barutnih gasova,

$\mathrm{Q}_{b}$ - sila težine oruđa $\mathrm{u}$ borbenom položaju,

R - ukupna sila otpora kretanju trzajuće mase,

$I=M \cdot d^{2} x / d t^{2}=F_{k n}-R-$ intercijalna sila trzajuće mase,

$\mathrm{N}_{\mathrm{k}}, \mathrm{N}_{\mathrm{a}}, \mathrm{H}_{\mathrm{a}}$ - sile reakcija tla $\mathrm{u}$ oslonim tačkama oruđa.
Uslov stabilnosti je zadovoljen ako je $\mathbf{M}_{\text {sta }}>0$.

Slično, $u$ odnosu na tačku oslanjanja točkova oruđa, može se postaviti uslov stabilnosti oruđa $\mathbf{M}_{\text {stk }}>0, \mathrm{tj}$.

$\mathrm{M}_{\text {stk }}=\mathrm{C}_{1} \cdot \mathrm{F}_{\mathrm{kn}} \cdot \mathrm{e}+\left(\mathrm{R}-\mathrm{Q}_{0} \cdot \sin \varphi\right)$.

$\cdot h_{k}+Q_{b} \cdot\left(D_{k}-D_{o}\right)+Q_{o} \cdot X \cdot \sin \varphi+$ $+\mathrm{H}_{\mathrm{a}} \cdot \Delta \mathrm{H}$

gde je:

$h_{k}$ - krak inercijalne sile trzajuce mase $u$ odnosu na oslonac točka, 
$\mathrm{H}_{\mathrm{a}}=\left(\mathrm{R}-\mathrm{Q}_{\mathrm{o}} \cdot \sin \varphi\right) \cdot \cos \varphi-$ komponenta sile reakcije tla na ašov.

Nepomičnost oruđa $u$ procesu lansiranja osigurana je ako je zadovoljen uslov $\mathrm{H}_{\mathrm{a}}>0$, odnosno pošto je $\varphi<\pi / 2$ rad sledi da je $R-Q_{0} \cdot \sin \varphi>0$.

$\mathrm{Za}$ pozitivan smer sile $\mathrm{R}$ usvojen je onaj u čijem pravcu sila $R$ teži da lafet oruđa pomeri suprotno od smera opaljenja.

\section{Stabilnost $i$ nepomičnost lafeta u procesu trzanja}

Za vreme trzanja, inercijalna sila trzajuće mase LAS ima smer delovanja u pravcu opaljenja (pozitivan smer), a sve ostale sile su iste kao i za proces lansiranja. oblik:

Sila ukupnog otpora trzanju ima $\mathrm{R}=\mathrm{F}_{\mathrm{p}}+\mathrm{Q}_{\mathrm{o}} \cdot(\mathrm{f} \cdot \cos \varphi+\nu)+\mathrm{V}_{\mathrm{t}}^{2} / \mathrm{A}_{\mathrm{t}}$, a moment stabilnosti oko oslonca ašova iznosi:

$\mathrm{M}_{\mathrm{sta}}=\mathrm{Q}_{\mathrm{b}} \cdot \mathrm{D}_{\mathrm{o}}-\mathrm{Q}_{\mathrm{o}} \cdot \mathrm{X} \cdot \cos \varphi-\mathrm{C}_{2} \cdot \mathrm{F}_{\mathrm{kn}} \cdot$

$\cdot e \cdot\left(1-C_{3} \cdot(1-\alpha) \cdot \beta /(\beta-0,5)\right)-$ $-\left(R-Q_{0} \cdot \sin \varphi\right) \cdot h_{a}$

Relacija (9) slična je izrazu (7), s tim što je uzeta u obzir i sila gasne kočnice.

Analogno tome može se definisati i moment stabilnosti za tačku oslanjanja točkova koji glasi:

$M_{\text {stk }}=C_{2} \cdot F_{k n} \cdot e \cdot\left[1-C_{3} \cdot(1-\alpha) \cdot \beta /(\beta-\right.$ $-0,5)]+\left(R-Q_{0} \cdot \sin \varphi\right) \cdot h_{k} Q_{b} \cdot\left(D_{k}-D_{o}\right)+$ $+\mathrm{Q}_{0} \cdot \mathrm{X} \cdot \cos \varphi+\left(\mathrm{R}-\mathrm{Q}_{\mathbf{0}} \cdot \sin \varphi\right) \cdot \cos \varphi \cdot \Delta \mathrm{H}$

Uslov nepomičnosti pri trzanju isti je kao u slučaju lansiranja.

S obzirom na značajnu razliku sile ukupnog otpora $\mathrm{R}$ za proces lansiranja i trzanja, u trenutku "prelaska" iz faze lansiranja $u$ trzanje, dolazi do porasta sile $R(t)$. Ovakva promena sile
$\mathrm{R}(\mathrm{t})$ može biti uzrok moguće nestabilnosti oruđa, o čemu treba voditi računa pri projektovanju LAS.

\section{Stabilnost pri dejstvu amortizera lansiranja}

Amortizer lansiranja treba da apsorbuje energiju lansiranja u slučaju neopaljenja ili »laganja metka«, kako cev ne bi velikom brzinom naletela na telo kolevke.

Amortizer lansiranja ne treba da deluje u prvom periodu lansiranja, niti $u$ drugom periodu ako je došlo do opaljenja. Pošto je trajanje drugog perioda lansiranja dosta kratko $u$ odnosu na ukupnu dužinu lansiranja (L), to je $i$ pređeni put lansirane mase $u$ ovom periodu relativno mali, tj. svakako će biti neposredno iza tačke gde je trebalo doći do opaljenja (dakle $u$ $\varepsilon_{0}$ - okolini "zahtevane" dužine lansiranja). Na osnovu iznetog, usvaja se da se na dužini $l=1,1 \cdot L$ od tačke početka lansiranja postavi graničnik koji će izvršiti aktiviranje amortizera.

Radi jednostavnosti i kompaktnosti konstrukcije treba nastojati da se amortizer izvede u obliku kočnice sa konstantnim ili promenljivim protočnim otvorima, sa što kraćim putem dejstva. To podrazumeva povećanu silu otpora amortizera, što utiče na smanjenje stabilnosti oruđa u procesu lansiranja.

$\mathrm{Na}$ osnovu navedenog, diferencijalna jednačina kretanja lansirane mase za period dejstva amortizera ima oblik:

$$
\begin{aligned}
& M \cdot \frac{d V_{1}}{d t}=F_{p o} \cdot\left(S_{o} /\left(S_{o}-L+\zeta\right)\right)^{n}- \\
& -Q_{o} \cdot(f \cdot \cos \varphi+\nu+\sin \varphi)-V^{2} / A_{1}- \\
& -V^{2}{ }_{1} / A_{A}
\end{aligned}
$$

gde je:

$$
A_{A}=2 \cdot a^{2}{ }_{A} / k \cdot \rho \cdot A^{3}{ }_{k A}-\underset{\text { amortizera, }}{\text { karakteristika }}
$$


$a_{A}, A_{k A}$ - površina protočnih otvora amortizera i radna površina klipa amortizera lansiranja.

Relacija (11) može jednostavno da se ugradi u programsko rešenje za numeričku integraciju, kao u slučaju jednačina (3) do (6).

Iterativnim približavanjem može se odrediti površina protočnih otvora amortizera kojom se obezbeđuje zaustavljanje lansirane mase na potrebnoj dužini dejstva amortizera.

Ako se proračun vrši po ovakvom modelu, stabilnost sistema LAS sa amortizerom može se odrediti po praktično istim relacijama kao u slučaju stabilnosti LAS u procesu lansiranja (8).

Pri tome se jedino menja sila ukupnog otpora lansiranju zbog delovanja amortizera, $i$ ona glasi:

$\mathrm{R}=\mathrm{F}_{\mathrm{p}}-\mathrm{Q}_{\mathrm{o}} \cdot(\mathrm{f} \cdot \cos \varphi+\nu+\sin \varphi)-$ $-\left(V^{2} / A_{1}+V^{2}{ }_{1} / A_{A}\right)$

Ako su mogućnosti obezbeđenja uslova stabilnosti ograničene s obzirom na druge zahteve LAS, treba razmotriti ugradnju trećeg kraka lafeta oruđa.

$\mathrm{Na}$ kraju teorijskog dela razmatranja problematike LAS, treba napomenuti da su pre pristupa projektovanju LAS nužna obimna eksperimentalna ispitivanja i uporedna analiza dobijenih rezultata sa proračunskim veličinama.

\section{Organizacija programskog modela LAS}

$\mathrm{Na}$ osnovu matematičkog modela principa rada LAS izrađeno je odgovarajuće programsko rešenje za određivanje proračunskih veličina i parametara pomoću personalnog računara [5]. Organizacija programskog modela prikazana je na slici 5 .
Programsko rešenje čine glavni program UBP za unutrašnjebalistički proračun sa potprogramima:

POMVRP - za određivanje priraštaja zavisnih i nezavisnih promenljivih, metodom Runge-Kutta sa promenljivim korakom,

FUNKP - za definisanje jednačina unutrašnje balistike (UB).

Potrebni ulazni podaci za UB proračun definišu se na ulaznoj datoteci ULUB, a proračunske veličine na datotekama IZUB i IZGB.DAT.

Osnovni program za proračun parametara LAS sadrži sledeće potprograme:

POMVAR - slično je kreiran kao u slučaju UBP,

FUNK - za definisanje diferencijalnih jednačina LAS,

HMIN - za traženje minimuma zadatog niza brojeva,

HMAX - za traženje maksimuma zadatog niza brojeva,

PBG - za linearnu interpolaciju podataka za pritisak barutnih gasova $\mathrm{u}$ zavisnosti od vremena,

IBG - za određivanje ukupnog impulsa gasova, uključujući period naknadnog dejstva i gasnu kočnicu,

$\mathrm{T} 1$

- za određivanje vremena za koje impuls barutnih gasova dostigne veličinu impulsa potrebnog za zaustavljanje lansirane mase.

Polazni podaci za proračun LAS definisani su na ulaznoj datoteci ULLAS, a izlazni rezultati proračunskih veličina na izlaznim datotekama: IZLAS.DAT (za parametre kretanja), STARO.DAT (za momente stabilnosti i sile ukupnog otpora trzanju za svaki 


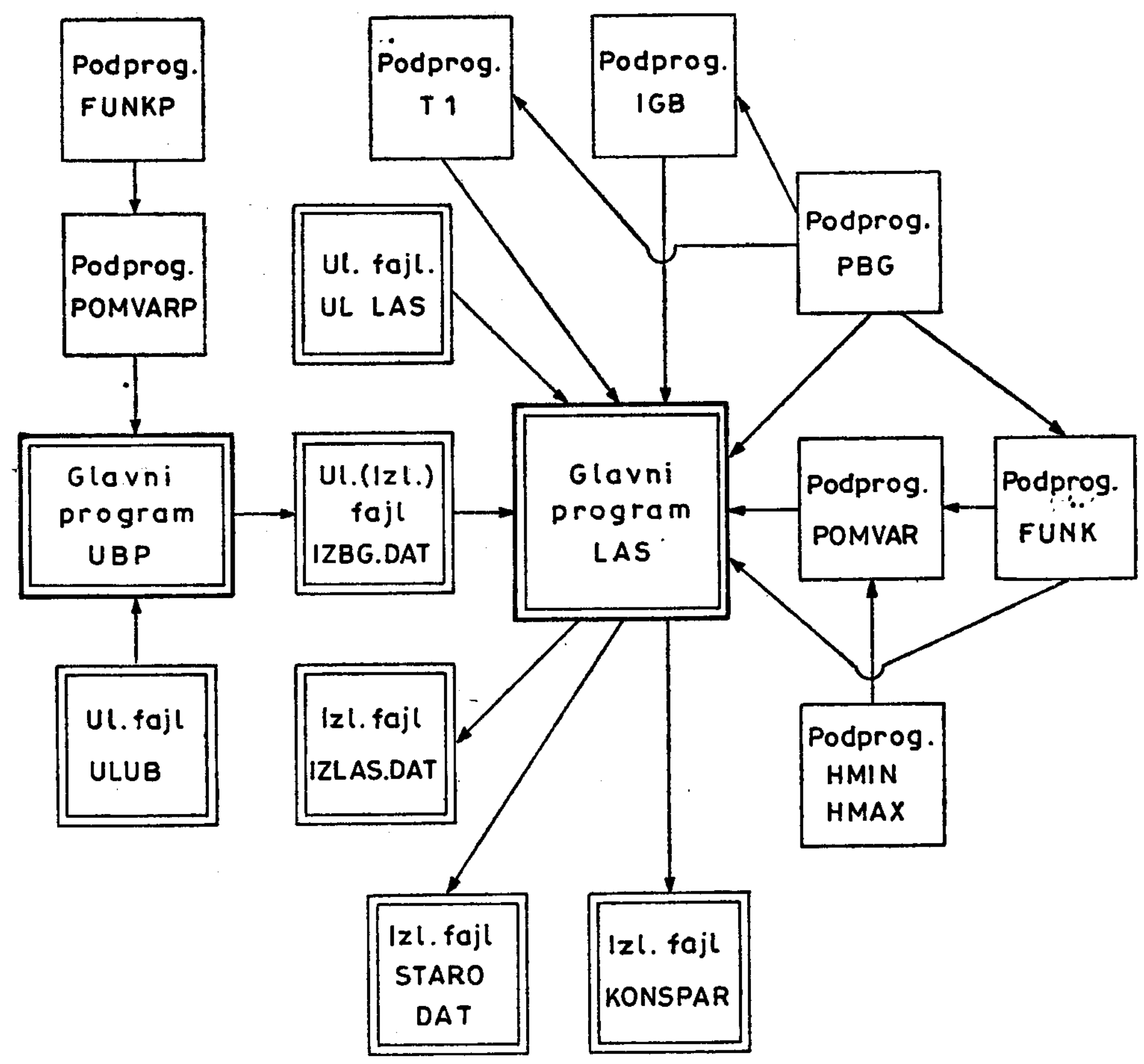

Sl. 5 - Organizacija modela za proračun LAS

trenutak procesa lansiranja - trzanja) i KONSPAR (vrednosti konstruktivnih parametara dobijenih proračunom LAS za odabrani primer oruđa).

\section{Primer proračuna LAS}

Testiranje programskog modela $\mathrm{i}$ proračun potrebnih veličina LAS izvršeno je na odabranom primeru lafetnog oruđa. Usvojeno je da se LAS projektuje na bazi PT topa kalibra 100 $\mathrm{mm}$ sa polaznim podacima koji su uzeti prema [5]. Dabijeni rezultati nekih od proračunatih veličina i karakteri- stika LAS dati su u tabeli 1 i grafički prikazani na slikama 6 do 11 . Vrednost koeficijenta iskorišćenja gasne kočnjce bila je 35\%.

Energija trzanja LAS, prema podacima u tabeli 1 iznosi oko 39\% energije slobodnog trzanja kod klasičnog artiljerijskog sistema za istu masu lafeta.

Koeficijent iskorišćenja mase lafeta $\left(\eta_{1}\right)$ ili energija trzanja po jedinici mase lafeta takođe je smanjen, što pruža mogućnost da se i masa lafeta smanji $u$ adekvatnom odnosu, a time znatno poboljša pokretljivost oruđa. 


\begin{tabular}{|c|c|c|}
\hline Veličine & 莺 & $\begin{array}{l}\text { PT top } \\
100 \mathrm{~mm}\end{array}$ \\
\hline $\mathbf{M}_{1}=\mathbf{M}_{\mathrm{b}}-\mathrm{M}, \quad$ masa lafeta & kg & 1380 \\
\hline $\mathrm{E}_{\mathrm{t}}=M \mathrm{MV}_{\mathrm{tm}}^{2} / 2$, energija trzanja LAS & $\mathbf{J}$ & 20911,15 \\
\hline$V_{k_{m}}=I_{w} / M, \quad$ brzina slobodnog trzanja & $\mathrm{m} / \mathrm{s}$ & 8,65 \\
\hline$\eta_{1}=E_{t} / M_{1}, \quad$ koeficijent iskorišćenja mase lafeta & $\mathrm{J} / \mathrm{kg}$ & 15,13 \\
\hline$\eta_{k}=E_{k} / M_{1}, \quad \begin{array}{l}\text { koeficijent iskorišćenja pri slobodnom } \\
\text { trzanju }\end{array}$ & $\mathrm{J} / \mathrm{kg}$ & 38,49 \\
\hline$\eta_{\mathrm{E}}=E_{\mathrm{t}} / \mathrm{E}_{\mathrm{k}} \cdot 100, \quad$ koeficijent energije trzanja & $\%$ & 39,37 \\
\hline$\eta_{\mathrm{i}}=\left(\mathrm{V}_{\mathrm{lm}} /\left(\mathrm{V}_{\mathrm{lm}}+\mathrm{V}_{\mathrm{tm}}\right)\right) \cdot 100, \quad \begin{array}{l}\text { impuls barutnih gasova za } \\
\text { zaustavljanje trzajuće mase }\end{array}$ & $\%$ & 36,60 \\
\hline
\end{tabular}

Oznake upotrebljene u tabeli 1 su:

$\mathrm{M}_{\mathrm{b}}$ - ukupna masa oruđa,

M - masa trzajućih delova,

$E_{k}$ - kinetička energija trzajuće mase klasičnog sistema oruđa pri slobodnom trzanju,

Iu - ukupni impuls barutnih gasova (uključujući period naknadnog dejstva gasova i gasnu kočnicu).

Proračunati parametri kretanja trzajuće mase, brzina $i$ put $u$ procesu lansiranja i trzanja prikazani su na slikama 6,7 i 8 .

Tok promene ovih parametara je $\mathrm{u}$ potpunoj saglasnosti sa podacima $u$ literaturi. Maksimalna brzina lansiranja LAS $\left(V_{\mathrm{lm}}=3,13 \mathrm{~m} / \mathrm{s}\right)$ manja je od maksimalne brzine trzanja $\left(\mathrm{V}_{\mathrm{tm}}=5,43\right.$ $\mathrm{m} / \mathrm{s}$ ). U odnosu na maksimalnu brzinu trzanja za klasičan sistem $V_{\mathrm{km}}=8,65$ $\mathrm{m} / \mathrm{s}$, veličine $V_{\mathrm{tm}}$ i $V_{\mathrm{lm}}$ su manje, što znači da je u sistemu LAS deo energije trzanja "utrošen" na lansiranje.

Dobijena vrednost $\mathrm{za} \quad \mathrm{V}_{\mathrm{lm}}=3,13$ $\mathrm{m} / \mathrm{s}$ iznosi približno $72 \%$ od vrednosti $\mathrm{V}_{\mathrm{km}} / 2=4,32 \mathrm{~m} / \mathrm{s}$, što je saglasno postavljenom zahtevu od $\approx 75 \%$. Istovremeno, ukupno smanjenje energije trzanja LAS, u odnosu na klasičan artiljerijski sistem (PT top $100 \mathrm{~mm}$ ), iznosi oko $61 \%$.
Iz dobijenih rezultata za uslove stabilnosti LAS prema grafičkim prikazima na slikama 9,10 i 11 , vidi se da

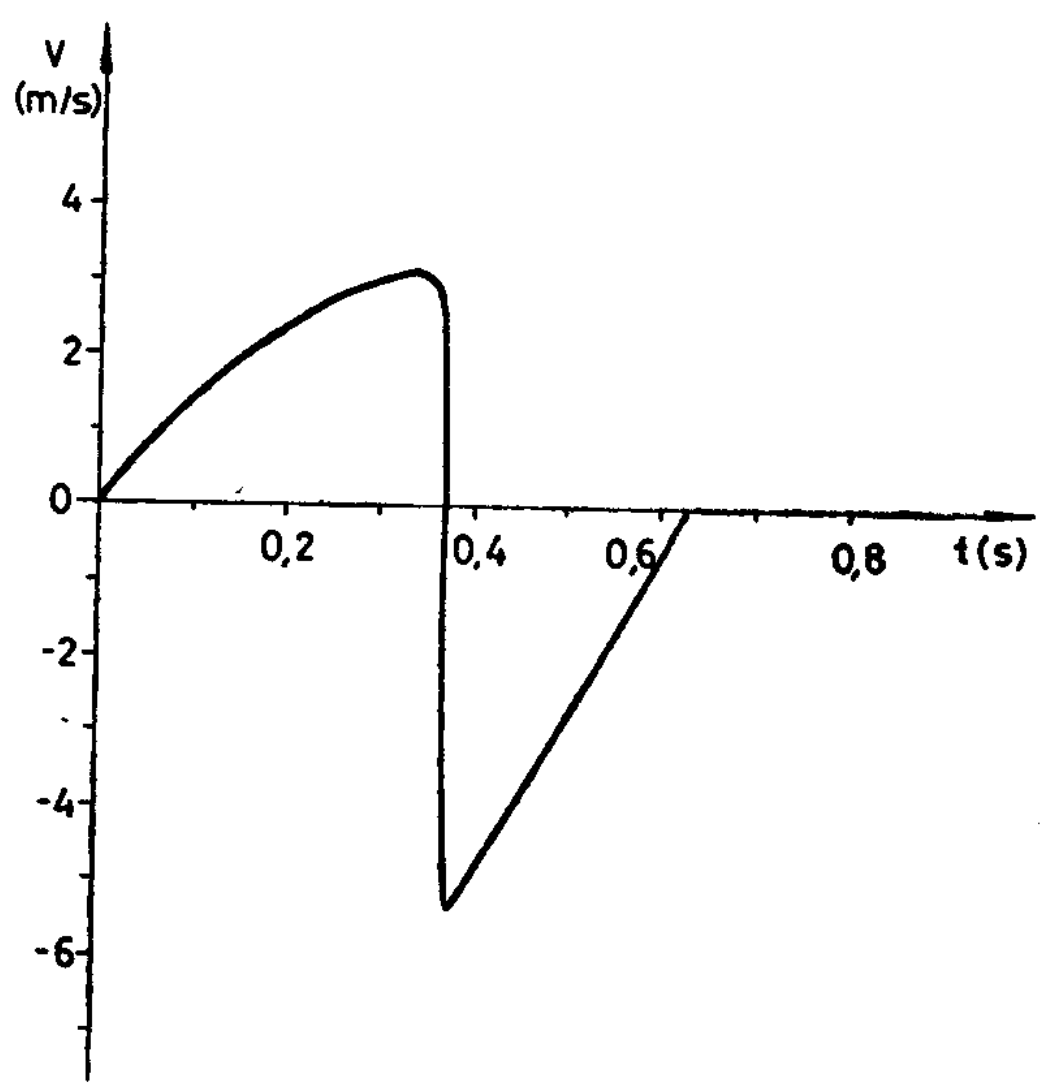

St. 6 - Brzina kretanja u funkciji vremena 
je sistem stabilan $u$ celom procesu lansiranja i trzanja.

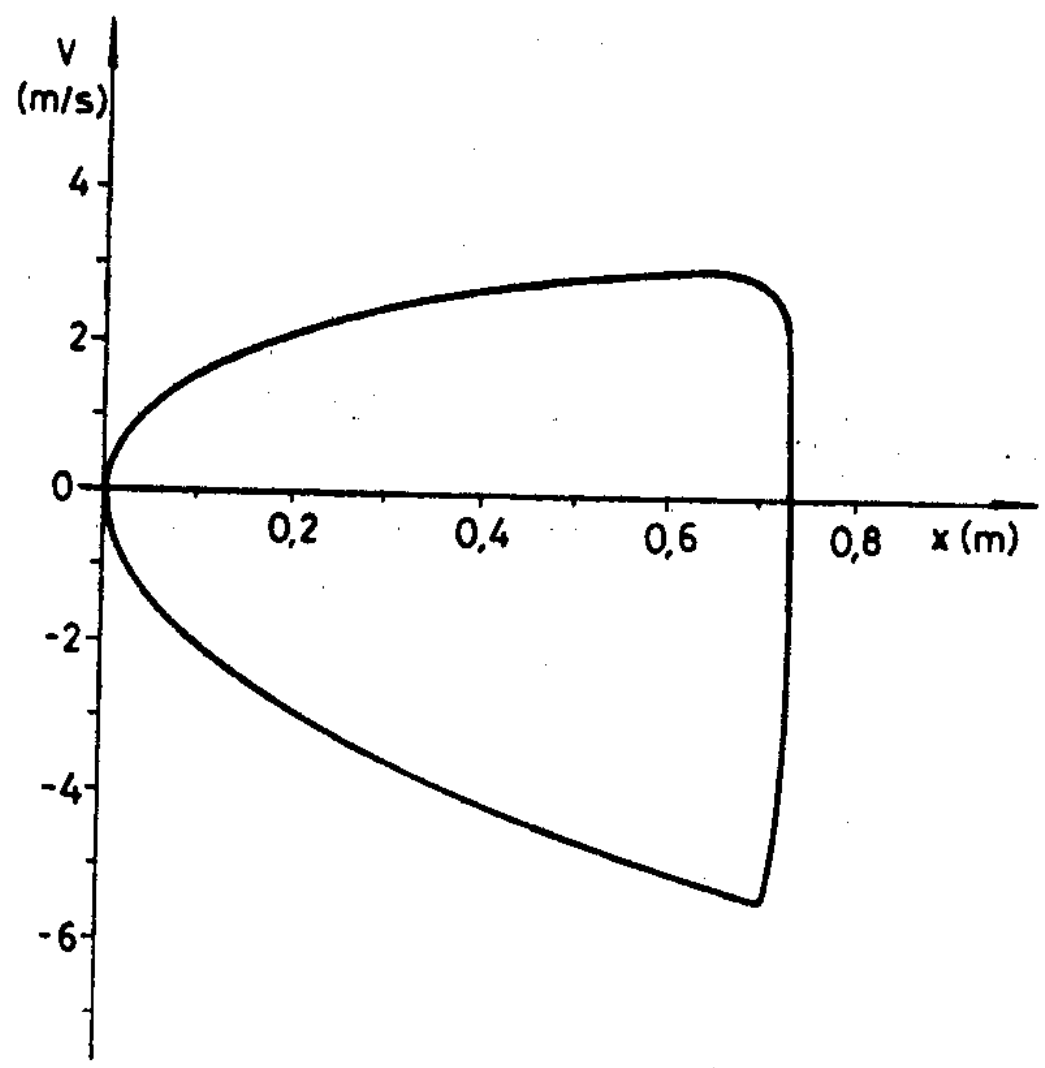

Sl. 7 - Brzina kretanja u funkciji puta

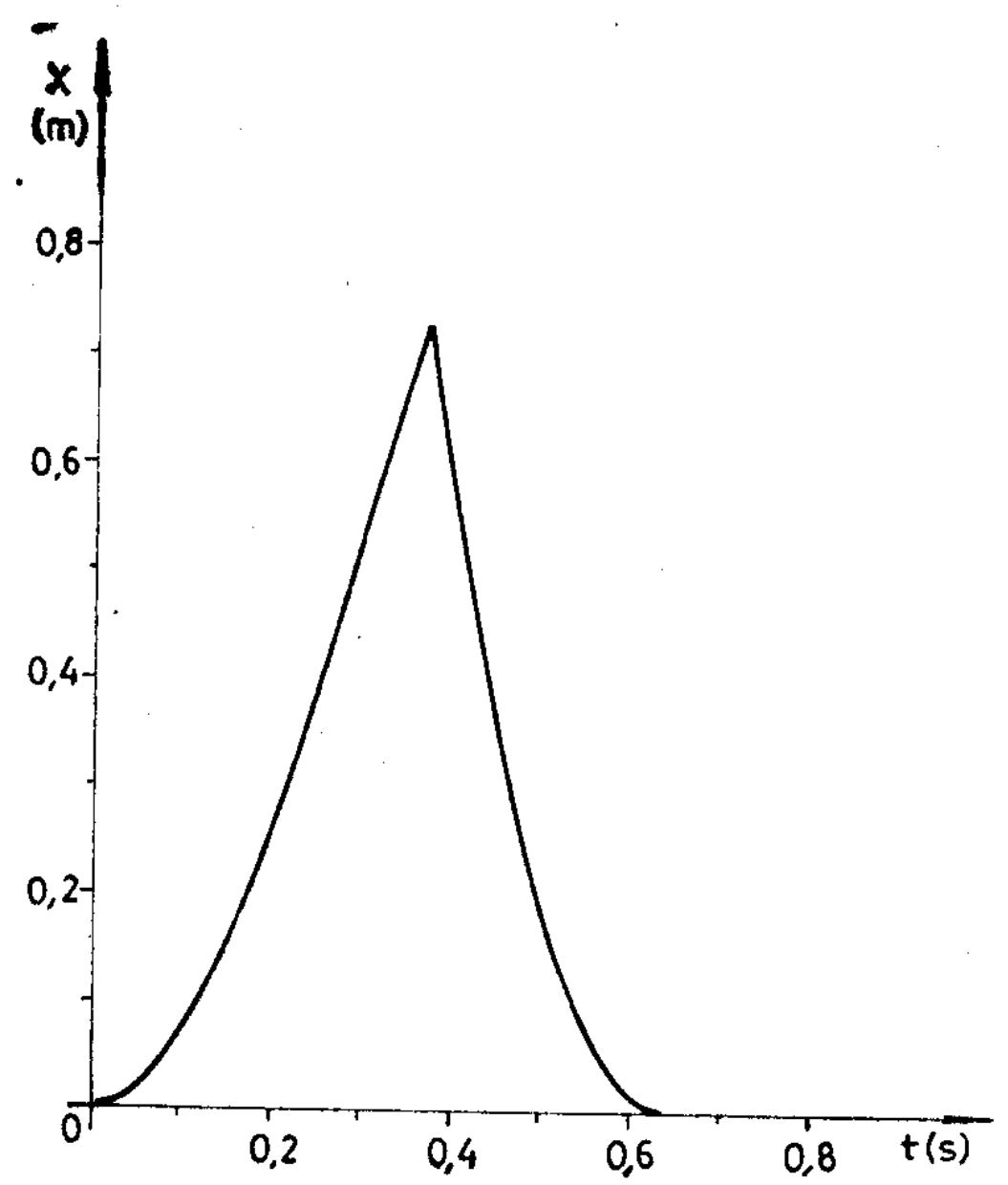

St. 8 - Put lansiranja $i$ trzanja cevi

Stabilnost LAS najviše je ugrožena za vreme dejstva sile pritiska barutnih gasova, kao i zbog nagle pro- mene smera sila koje su konstitutivni članovi ukupnog otpora trzanju $R(t)$.

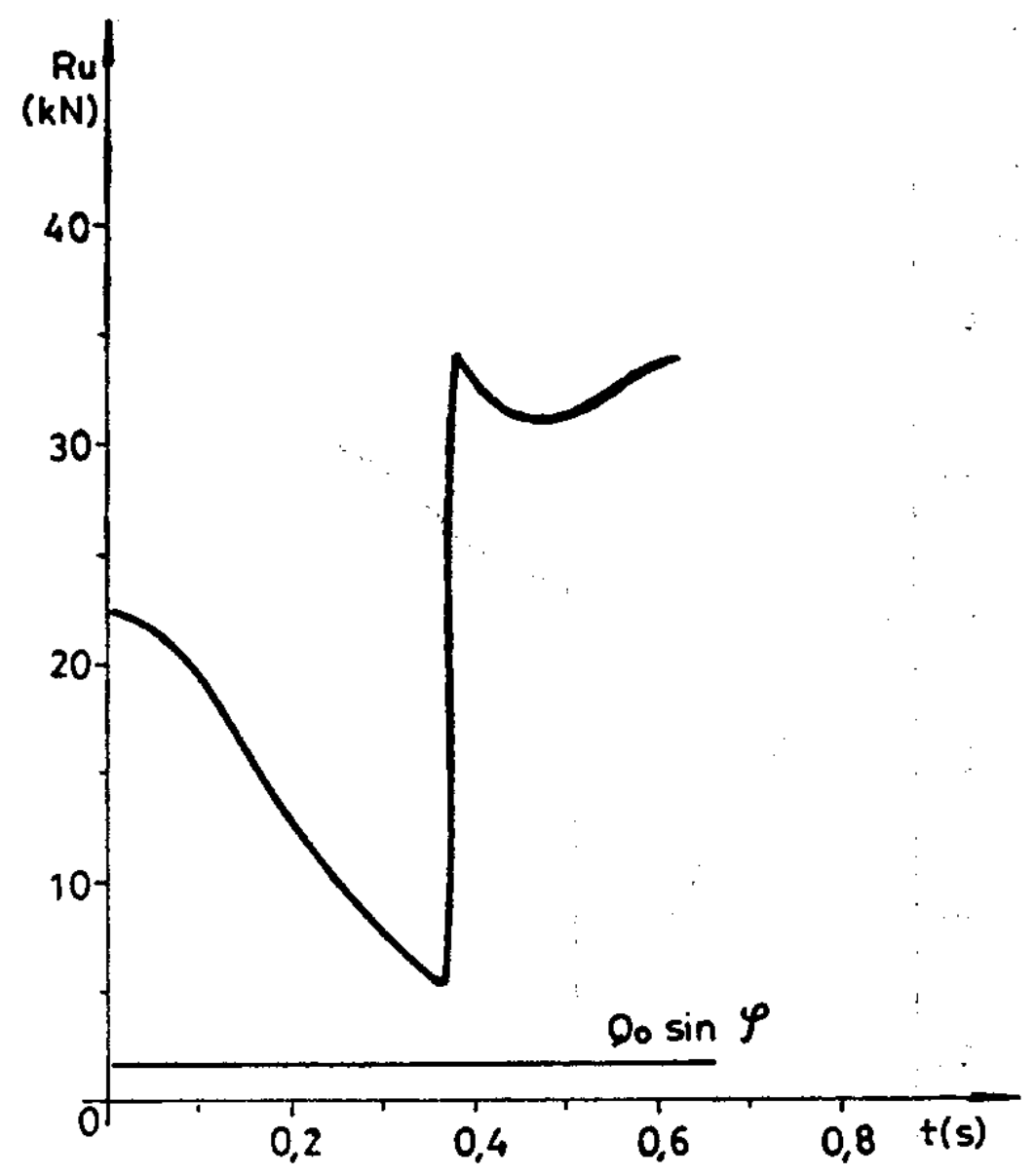

St. 9 - Promena ukupne sile otpora trzanja

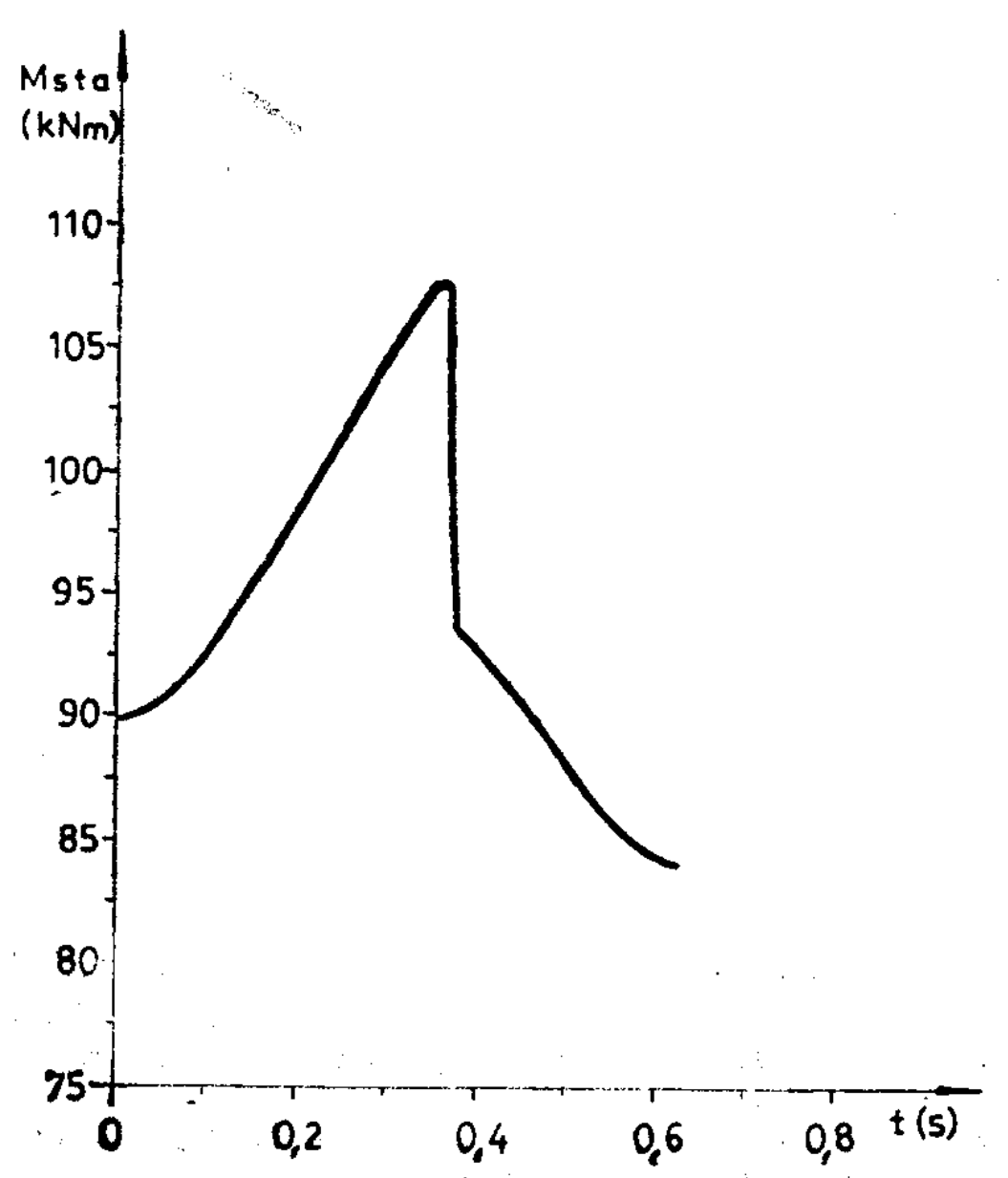

Sl. 10 - Moment stabilnosti oko oslonca ašova 
Upoređivanjem vrednosti granične sile otpora trzanju $\mathrm{R}_{\mathrm{gr}}=119,3 \mathrm{kN}$ klasičnog artiljerijskog sistema na osnovu kojeg je proračunat LAS, u najnepovoljnijem slučaju $\left(F_{k n}=F_{k n \text { max }}\right)$ i maksi-

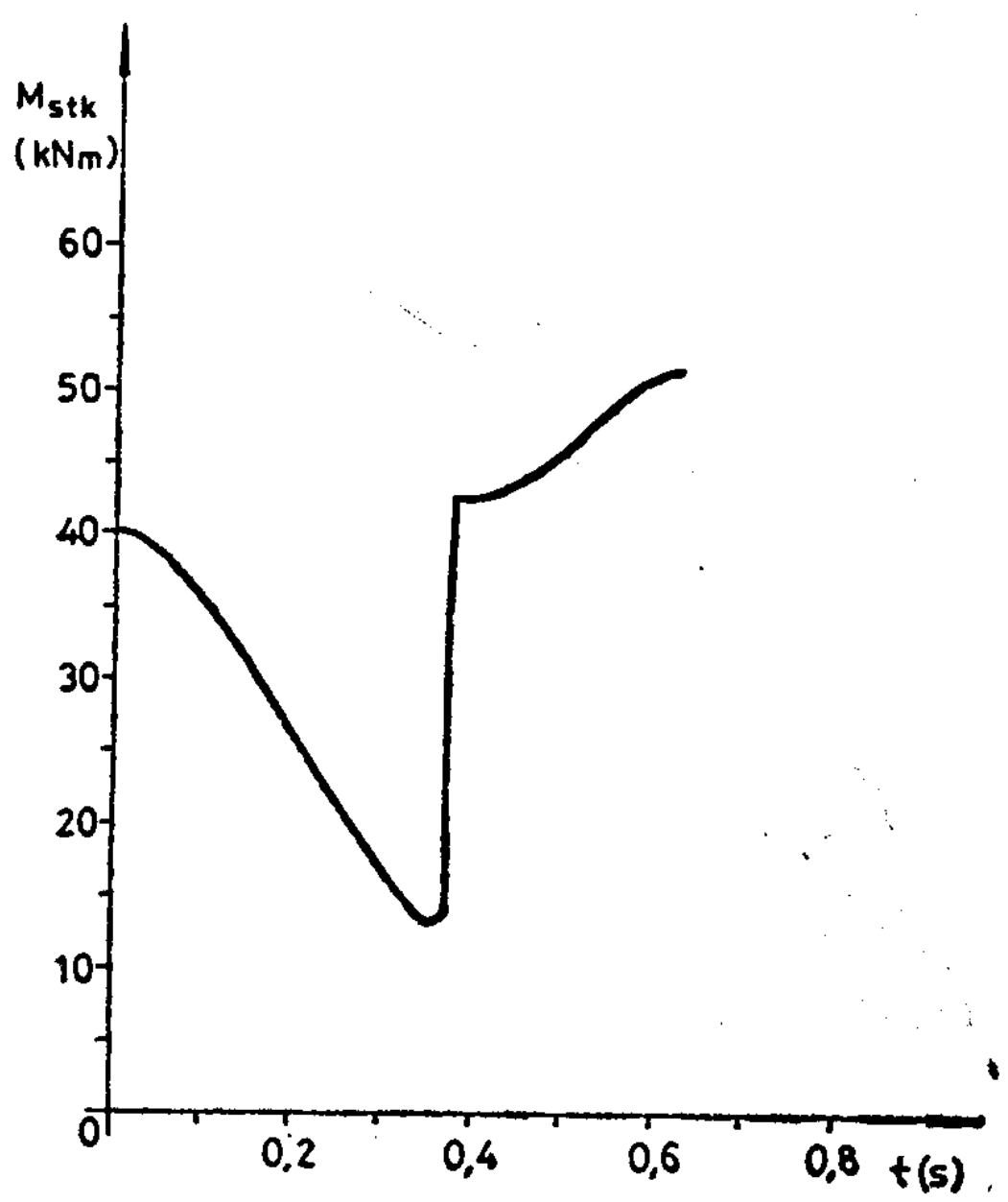

Sl. 11 - Moment stabilnosti oko oslonca točkova

malne sile ukupnog otpora za pripadajući LAS, tj. $R_{m}=34,5 \mathrm{kN}$, lako se zaključuje da je sa projektovanim LAS postignuto znatno smanjenje sile otpora $R(t)$, pa, prema tome, $i$ znatno rasterećenje lafeta oruđa.

\section{Zaključak}

Simulacijom programskog modela LAS na konkretnom primeru oruđa do- bijeni su proračunski rezultati najvažnijih veličina LAS, koji omogućavaju dalji rad na ovom problemu. Ostale karakteristične veličine potrebne za projektovanje LAS su:

- zahtevana dužina lansiranja (trzanja): $0,74 \mathrm{~m}$,

- proračunska dužina lansiranja (trzanja): $0,73 \mathrm{~m}$,

- put lansiranja u trenutku opaljenja: $0,72 \mathrm{~m}$,

- brzina lansiranja $u$ trenutku opaljenja: $3,13 \mathrm{~m} / \mathrm{s}$ (maksimalna), $0,36 \mathrm{~s}$,

- vreme do trenutka opaljenja:

- površina protočnih otvora kočnice lansiranja: $5,18 \mathrm{~cm}^{2}$,

- površina protočnih otvora kočnice trzanja: $9,90 \mathrm{~cm}^{2}$,

- ukupan impuls sile barutnih gasova: $12281,15 \mathrm{Ns}$,

- impuls sile barutnih gasova za zaustavljanje trzajuće mase: 6084,7 . Ns, $\mathrm{kN}$.

- početna sila povratnika: 11,36

Prikazani rezultati na osnovu teorijskog razmatranja principa rada LAS, upućuju na opravdanost daljeg istraživanja ovog problema u okviru modifikacije postojećih rešenja lafetnih artiljerijskih oruđa i povećanja njihovih borbenih mogućnosti.

Iako primena LAS ima nedostataka, o čemu nije bilo reči, izneta ideja uz primenu razvijenog programskog modela pruža solidnu osnovu za dalju analizu radi dolaska do optimalnog $i$ svrsishodnog rešenja.

\section{Literatura:}

[1] Paligoric, A.: Teorijske osnove principa rada LAS, NTP br. 9-10 (161-182), Beograd, 1970.

[2] Kalezić, M.: Projektovanje vučnih art. oruđa, VTI, Beograd, 1984.

[3] Toločkov, A.: Teorija lafetov artillerijskih ustanovok, Oborogniz, Moskva, 1960.

[4] Gordienko: Teorija i rasčot artillerijskih orudij, Oborogniz, Penza, 1967.

[5] Davidović, M.: Diplomski rad, VTA, Beograd, 1993. 